\title{
Specialized Accounting Inspection: study on the perception of the Trial judges in the Labor Court System about the quality and relevance of the specialized investigation job of experts
}

\author{
Perícia Contábil: estudo da percepção de juizes de Primeira Instância na Justiça do \\ Trabalho sobre a qualidade e a relevância do trabalho do perito
}

\section{Pericia Contable: estudio de la percepción de los jueces de Primera Instancia en el Tribunal del Trabajo sobre la calidad y la pertinencia de la labor del perito}

\author{
Idalberto Jose das Neves Júnior ${ }^{1}$ \\ Simone Alves Moreira ${ }^{2}$ \\ Elisangela Batista Ribeiro ${ }^{3}$ \\ Moacenira Cardoso da Silva ${ }^{4}$
}

Received on March 30, 2012 / Approved on April 25, 2013

Responsible Editor: Ivam Ricardo Peleias, Dr.

Evaluation Process: Double Blind Review

\begin{abstract}
The court appointed experts have means to inform and elucidate the judge, guiding him in his decisions, since it can't be expected that judges are scientists or technicians in all matters, since there are matters that need clarification and certification of professionals deserving full faith in all technical, moral, scientific and legal aspects. Thus, the burden shouldered by the Judge is shared with the Expert who instructs him with the certification of causes and events through his expertise and requirements of morality and
\end{abstract}

honesty. Within this context, this study aimed to know the opinion of the Trial judges working in the Labour Court System on the quality and relevance of the work done by the accounting expert. To this end, we have carried out a field research with 135 Trial judges of the Labor Court System in all regions of Brazil. The multivariate statistical technique of cluster analysis was used to better study the cases. The results of this survey revealed that $58 \%$ of respondents regard the work of the expert accountant as good and necessary, and that $71 \%$ of the judges consider the work of

* The authors are grateful to Prof. André Luiz Cordeiro Cavalcanti for allowing the conduction of the field survey with the judges working as Trial Judges in the Brazilian Labor Court System.

1. Master of Knowledge Management and Information Technology Professor at the Catholic University of Brasília (UCB). Manager of the Controllership Directorate Division of the Bank of Brazil. [jneves@ucb.br]

2. Specialist in Accounting Audit and Specialized Investigation. Professor at the Catholic University of Brasília (UCB). [simonea@ucb.br]

3. Graduate of Accounting Sciences from the Catholic University of Brasília (UCB). [elisribeirof@gmail.com]

4. Graduate of Accounting Sciences from the Catholic University of Brasília (UCB). [cenira.cardoso@gmail.com] Authors' address: QS 07 Lote 01 - EPCT - Águas Claras, Brasília-DF - CEP 71966-700 - Brazil 
the expert accountant relevant to support their decisions. However, the judges have shown the main failures found in the work of the accountantexpert as well as suggestions for improvement.

Keywords: Legal expert work. Expert work in the labor field. Accountant-expert.

\section{RESUMO}

A perícia tem meios de cientificar e elucidar o julgador, orientando-o em suas decisóes, uma vez que náo se pode esperar que os magistrados sejam cientistas ou técnicos em quaisquer assuntos, visto que há matérias que precisam de esclarecimento e certificação de profissionais merecedores de inteira fé, nos aspectos técnicos, moral, científico e legal. Destarte, a carga que pesa sobre o Juiz é dividida com o Perito, que o instrui com a certificação de causas e fatos por meio de suas qualidades de especialista e requisitos de moralidade e honestidade. Dentro desse contexto, este estudo objetivou conhecer a opinião dos juízes que atuam na Primeira Instância da Justiça do Trabalho acerca da qualidade e relevância do trabalho desenvolvido pelo perito contábil. Para tanto, realizou-se uma pesquisa de campo com 135 juízes da Primeira Instância da Justiça do Trabalho e em todas as regióes do Brasil. Foi utilizada, ainda, a técnica estatística multivariada de análise de clusters para melhor estudo dos casos. Os resultados obtidos nesta pesquisa revelaram que $58 \%$ dos entrevistados consideram como bons e indispensáveis o trabalho desenvolvido pelo perito-contador e que $71 \%$ dos magistrados consideram o trabalho do perito relevante para subsidiar sua decisão. Foram apresentadas pelos magistrados, contudo, as principais falhas encontradas no trabalho do perito, bem como sugestôes de melhoria.

Palavras-chave: Perícia judicial. Perícia trabalhista. Perito-contador.

\section{RESUMEN}

La pericia dispone de medios para dotar de conocimientos y dilucidar al juez, la dirección de él en sus decisiones, ya que no se puede esperar que los jueces sean los científicos o técnicos en todos los asuntos, ya que hay asuntos que necesitan la clarificación y certificación de profesionales plenamente cualificados para los aspectos técnicos, morales, jurídicos y científicos. Por lo tanto, la responsabilidad del juez se comparte con el perito que lo instruye con la certificación de las causas y los acontecimientos a través de sus cualidades de los peritos y exigencias de moral y honestidad. Dentro de este contexto, el presente estudio tuvo como objetivo conocer la opinión de los jueces que actúan en primera instancia del Tribunal de Trabajo sobre la calidad y la pertinencia de la labor realizada por el perito contable. Con este fin, se llevó a cabo la investigación de campo con 135 jueces de la Corte de Primera Instancia de Trabajo y en todas las regiones de Brasil. Se utilizó la técnica estadística multivariante de análisis de cluster para estudiar mejor los casos. Los resultados de esta encuesta revelaron que el 58\% de los encuestados consideran como bueno y necesario el trabajo del perito contable y que el $71 \%$ de los jueces consideran el trabajo de los peritos como relevante para apoyar su decisión. Sin embargo, los magistrados indicaron fallos importantes en la labor del perito, y sugirieron mejoras.

Palabras claves: Pericia judicial. Pericia laboral. Perito contable.

\section{INTRODUÇÃO}

The legal accounting expert work is one of the means of evidence at the disposal of people litigants of the legal proceeding - having the aim of giving light to the truth of the facts in a report called accounting expert report, aiming to generate information to help the judge taking a decision.

In the understanding of Sá (2010), the accounting expert work is to check estate-related facts with the aim of issuing an expert opinion by the use of some procedures - examination, evaluation, arbitrage, etc. - to materialize the expert report.

To Alberto (1996), the expert work is a way to verify, to prove or to demonstrate, with 
the use of scientific techniques and methods, with the aim of identifying and materializing the truth of the facts in a formal truth.

Thus, we can infer from these authors that the legal accounting expert work has the aim of subsidizing the judge's decision by means of delivering the expert report, in which the expert - with the use of procedures (scientific techniques and methods) - demonstrate the truth of the facts about the estate.

In regard to the conduction of the legal accounting expert work, it is applicable within the scope of labor lawsuits conducted in the Labor Courts System, in which employers and employees can discuss the disputes of the sector.

In this context, labor lawsuits have their venue in the Labor Court Systems, an organism of the Judicial Power, pursuant to article 93 of the Federal Constitution. Mostly, those lawsuits take place when employers or employees feel harmed. Most of the cases take places upon the employment agreement rescission, when there is no personal or collective agreement on the rights determined by the laws that govern the employeremployee relationship (CAVENAGE, 2004).

Corroborating this idea, Magalhães and Lunkes (2008, p. 7) say that "the labor lawsuits specifically aim the responsibility in situations of dangerous and unhealthy work, and in general the verification of the employees' demands, in individual or collective lawsuits, in regard to salary and remuneration differences, and the reflexes of such differences. It can be also originated in lawsuits of employers against employees".

Recent data, included in the General Report of the Labor Court System, show that in 2009 , within each group of 100,000 inhabitants of the country, 82 have filed a lawsuit or appeal in the Superior Labor Court, 281 in the Regional Labor Courts, and 1,101 in the Labor Courts. There was an increase of $7.36 \%$ in relation to 2008 (SUPERIOR LABOR COURT, 2009).

In areas as the Labor Court System, the work of experts is much needed. The presence of the accountant is compulsory when the expert work objective is to investigate accounting aspects; when the issue of labor calculations is explicit, such calculations have to be performed by a qualified accountant (CAVENAGE, 2004). Specially, the work of the accountant-expert occurs in the phase of the sentence liquidation, in which the Court expert does the labor calculations.

Thus, it is important to highlight the quality and relevance of the accountant-expert services, because these reports will be the basis for the decision-making. Considering the relevance of the work produced by the accountant-expert, it is noteworthy the importance of the quality factor which should be intrinsic to the work produced and delivered to the judge.

Reflecting about this issue, Sá (2010, p. 8) highlights that "the quality of the professional almost always governs the quality of the executed work. However, there are essential requirements to regard an expert investigation as a quality one". In addition, the quality of the presented work and its reliability is what makes it relevant, essential to be the basis of the judge's decision.

As for the findings in similar studies, it was possible to evidence the report as an important and necessary instrument for the judge's decisionmaking process. However, there are things to say about the quality of the works produced by the accountant-experts, such as (CESTARE; PELEIAS; ORNELAS, 2007; LEITĀO JÚNIOR et. al., 2012; NEVES JUNIOR; MEDEIROS, 2006; NEVES JUNIOR; RIVAS, 2007):

- lack of description of the parameters and their foundations for the elaboration of reports;

- use of excessively refined texts;

- excessive utilization of technical terms;

- use of ambiguous sense or imprecise words;

- important omissions, such as the absence of the record of diligence terms and the suppression of the information on the expert professional category.

In view of this problem-situation, the research matter can be outlined as follows: what is the quality and relevance of the accountantexpert work in labor disputes in the opinion of Trial judges of the Labor Court System? 
Therefore, the main objective of this work is to evidence the quality and relevance of the accountant-expert work in labor disputes in the opinion of Trial judges of the Labor Court System. The specific objective is the following: search for the main failures committed by the accountantexpert in the labor field in developing his work.

\section{THEORETICAL REFERENTIAL}

\section{I Fundaments of the accounting expert work}

The accounting expert work has the aim of materializing the truth of the facts in an accounting expert report to provide subsidies for the decision-making process of his main client: the judge. To that end, the expert develops a set of technical-scientific procedures that safeguard the accounting expert work.

Such procedures comprise activities related to the stages of planning and execution of the expert investigation, intended to take to the decision stage those evidence elements necessary to subsidize the fair solution of disputes, through the production of an accounting expert report and/or accounting expert opinion (CFC, 2009b).

Also from the conceptual viewpoint, Magalhães and Lunkes (2008) define the expert investigation as an elucidative and technical evidence mean accepted in the Code of Civil Procedure (CPC) that comprises the opinion of a professional expert on the matter under trial. In addition, it also comprises the definition of the technical evidence as the human testimony of the existence and truthfulness of things and facts and, as the opinion, is the authorized opinion of someone that deeply knows the questioned matter.

To Hoog (2008), the accounting expert investigation is a technology of the Accounting Sciences, and offers a mean of evidence which has the aim of explaining the reality of facts through the production of an accounting expert report in order to subsidize the legal assurance of the judge to make his decision as a legal judgment.

As a mean of technical evidence at the service of the justice, it is mostly demanded in disputes taking place in the Federal Court System, in the Labor Court System and in the State Court System, in lawsuits involving estate rights of natural persons and legal entities. The main types of disputes that require the accounting expert work are the following: civil in general, criminal, probate and family, bankruptcy, administrative, tax and labor responsibility (MAGALHĀES; LUNKES, 2008).

About the procedures for the expert investigation planning and execution, Ornelas (2003) points out that there are two fundamental aspects of the process: what is being demanded and the time when the facts have occurred.

In regard to the execution of the expert work and to support such work, the expert will develop the field work usually done out of the records, and in the way of diligences that, according to art. 429 of the CPC, consists of all necessary licit means to obtain evidences that can be outside the records (BRASIL, 2003).

After conducting the diligences, the production of the expert evidence will be produced by means of the elaboration of the report, of the opinion and of the audience document. The report is elaborated by the Court expert; the opinions are written by the assistant experts. The audience document is elaborated by the judge, and might contain information given by the expert, the assistants and other persons heard (MAGALHÁES; LUNKES, 2008).

Also about the procedures of the accounting expert work planning and execution, the research sources of the Federal Council of Accountancy - CFC (2009b), of Magalhães and Lunkes (2008), of Hoog (2008), of Ornelas (2003) and of the Code of Civil Procedure (BRASIL, 2003), converge and complement each other insofar they establish the work cycle of the accountantexpert, highlighting the importance of the work of such professional and his activities aiming at the transparency, grounding and excellence of the accounting expert report.

About the excellence of the accounting expert report, there is the quality of the work developed by the accountant-expert. According to Sá (2010), the good quality of the expert 
report should be associated to the compliance with the requirements of objectivity, technical strictness, concision, argumentation, preciseness and clearness. This author says that the report is a specialist piece, in which its structure should provide a duly argued and grounded opinion, aiming to explain the problem-situation under discussion.

In view of the presentations of such authors, it is possible to infer the importance of the expert work aiming to generation information to subsidize the judge's decision, and the need of developing a good quality expert report, which will contribute for the reading and use of such technical evidence.

\subsection{Technical evidence and its relevance}

The technical evidence is about the verification of the truth or the reality of certain facts, which is done by means of the examination by experts or technicians, who try to help the judge correctly deciding according to the conclusions presented in the report.

In the vision of Alberto (1996, p. 21) "as the character of the evidence is the characteristic most present in the expert instrument, it is important to consider and to situate the expert work, judicially known, also as expert evidence, in the context of evidences admissible by law". Thus, it is noteworthy that the character of the expert technical evidence is the most relevant predicate in the instrument of the expert work realization.

In regard to labor lawsuits, the expert evidence production can be ordered by the judge or by him upon the request of the parties. The evidences admitted by the Consolidation of Labor Laws (CLT) are listed in arts. 342 to 420 of the Code of Civil Procedure (CPC): personal testimony of the party, witnesses, documents, expert works and judicial inspection (ANGER, 2004).

The accountant-expert work is ancillary to the justice in elucidating the object under discussion by the litigants of the lawsuit. Thus, the accountant-expert will contribute to the justice and to the society insofar he explains the truth of the accounting facts and/or makes the labor calculations for the liquidation of the labor judgment.

Therefore, "the accountant is a professional of public faith, and his function as complex as big is the sum of conflicting interests, assuming the responsibility of his statements that are, at last, 'support point' for the decisions of judicial authorities, and for the definite solution of disputes of economic and/or pecuniary nature, sometimes being fundamentally important in the application of the justice for the broad interest of the society". (MAGALHÂES et al., 1998, p. 21).

About the labor law, CLT also stipulates, in its art. 852-H, that: " $\$ 4$ only when the evidence in fact demands, or it is legally imposed, the technical evidence will be granted, the judge being responsible for determining the time, the expert work object and the expert appointment as soon as possible" (ANGER, 2004, p. 115). Corroborating this aspect, the CPC, in its art. 421 , stipulates as follows: "when the evidence of the fact depends on the technical or scientific knowledge, the judge will be supported by an expert" (BRASIL, 2003, p. 92). When it is a evidence produced by an expert, the judge shall appoint the expert, observing the provision of art. 145: " $\$ 1$ The experts shall be selected amongst professionals with university degree, duly enrolled with the competent professional association, respecting the provision of Chapter VI, section VII, of this Code" (BRASIL, 2003, p. 46).

The $\$ 2$ of this article also states: "The experts shall prove to be specialists in the matter about which they will have to give an opinion, upon the submission of a certificate of the professional association with which they are enrolled" (BRASIL, 2003, p. 46). We can also mention as qualifications to perform such function that the expert shall be a legally, culturally and intellectually qualified professional, having moral and ethical virtues, always manifesting absolute commitment with the truth (SÁ, 2010).

In regard to the $\mathrm{CPC}$ and to the qualification statement made by Sá (2010), it is noteworthy that the fact of the accounting professional being duly enrolled with the Regional Council of Accountancy (CRC), which ensure 
the legal performance of the expert work, does not certifies him to be a qualified expert. Furthermore, in regard to the Brazilian Standards of Expert Work and qualification actions for such professionals, little is offered to qualify such experts.

Under such circumstances, there are still a lot to be done to improve the qualification of experts, and to contribute to the good quality of the work performed by such professional. Anyway, the Accounting-Expert Work is an important instrument for decision-making in the Labor Court System, since it subsidizes the judge and the involved parties in the lawsuit. Therefore, the accountant-expert work shall contribute, in an analytical manner and with the required quality, with an expert report that explains the estate aspects and/or labor calculations, leading to an appropriate and correct analysis of the dispute under discussion, solving any doubts in regard to the object of the expert work.

\subsection{Labor Court System and Labor Judicial Expert Work}

Amidst the various field of activities in the legal sphere, there is the accounting expert work of the labor lawsuit, which is demanded in nearly all disputes, especially in the phase of liquidation and execution of the judgment, when it becomes necessary to quantify the exact monetary expression contained in the executive title, although it can also take place during the fact-finding stage, when the judge, in the pursuit of subsidies to sustain his judgment, appoints an reliable expert to produce the accounting expert evidence (CARVALHO; MARQUES, 2005).

Therefore, it is the judge's prerogative, during the labor lawsuit and when necessary, to appoint the accountant expert to help him in the proceeding, and this can take place both in the fact-finding phase, which is the moment before the entry of the judgment, as well as during the liquidation of the obligations included in the decision command, i.e., after the judgment has become unappealable.

According to Alberto (1996), the accounting expert work in labor lawsuits occurs in two occasions: in the verification of the employee's receivables in the employers' estate; and in the analysis of the employers' estate values, on the occasion of labor lawsuits in which collective labor disputes are discussed.

According to Neves (2000), in order to guide the elaboration and presentation of calculations in the judgment liquidation phase, with the purpose of accelerating the execution, there are basic criteria and rules to be observed that, in addition of making calculations objective and transparent, will evidence the so-called new facts of the liquidation through articles that demonstrate data and procedures applied, such as: get to know the object of the cause, data, information and explicatory notes, disposition of the updated value, adjustment for inflation and interests, financial statements, as well as the loyalty to the judged and professional ethics. As new facts, we understand the elements submitted by the litigants to the proceeding, which lead to different interpretations resulting in different amounts on the occasion of the judgment liquidation.

It is recommendable that the expert, when making the labor calculation, starts the work by reading the initial and the answer itself, becoming familiarized with the object under discussion. The entire reading of the judgment, however, is indispensable, with the analysis of all items. It should also be observed whether there was an appeal, being necessary to read the appellate decision, which can partially or totally reform, or even, keep the primary judgment (NEVES, 2000).

The comments of Carvalho and Marques (2005), of Alberto (1996), and of Neves (2000) allow to identify the moment when the accountantexpert should work - in the verification of receivables and/or in the elaboration of labor calculations -, as well as the necessary procedures to develop the expert work, listing the documents and aspects to be observed in planning and executing the labor expert work.

It is noteworthy that the expert is entitled to a fair remuneration for his work. To that end, a proposal of fees is elaborated, in which the expert should consider the following factors: relevance, scale, risk, complexity, quantity of hours, technical 
staff, deadline, payment manner and interprofessional reports, among other factors (CFC, 2009a).

It should be pointed out that, in the Labor Court System, it is not possible for the expert to demand the payment of fees before starting the diligences, and the advanced payment is not compulsory. Thus, the proposal of fees should be done in a special and filed request, in separate, at the same moment when the expert report is delivered or after that (MAGALHÂES; LUNKES, 2008).

CLT stipulates the following about the expert fees: "art. 790-B. The responsibility for paying the expert fees is of the lawsuit losing party, except if such party is beneficiary of the free provision of legal advice" (ANGER, 2004, p. 108). Thus, the Superior Council of the Labor Court System (CSJT) has issued the Resolution 35 ruling the payment of expert fees in labor lawsuits. According to this Resolution, all the Regional Labor Courts shall reserve, in their budget, a sufficient amount to pay expert fees in lawsuits where the losing party is a destitute person beneficiary of free legal advice (HONORÁRIOS, 2010).

The amount of fees shall be the maximum one, being the judge responsible for defining the respective value (art. 3). The expert fees can only be released after the judgment becomes unappealable (art. 2, III). Resolution 35/CSJT/2007, however, also mentions the advanced payment of fees (art. $2, \S 2$ ), saying that "there could be" the advance payment, which is not necessarily demandable.

Therefore, for not being surprised with an amount incompatible with the work developed, the submission of the fees proposal for discussion and homologation by the judge before starting the works is recommendable, especially in labor lawsuits of large scale (MAGALHĀES; LUNKES, 2008).

\subsection{Quality in the provision of accounting expert services}

The quality of the accounting expert report is related to the expert capacity of producing the technical evidence in a detailed manner, with clearness and objectivity, duly grounded and with a technical reasoning that allows the report user to understand and clear up the truth of the facts. To Sá (2010, p. 11), "the quality of the expert work is reflected on how reliable his report and opinion is in the eyes of those using them. The expert report is a piece with high responsibility which requires quality, and which should meet the special requirements pertinent to it".

Corroborating with Sá (2010), Gray (2008) says that the expert in a lawsuit or in a court needs to apply the principles of reliability, and acceptable elements or data in developing the expert work, since this professional is a specialist acknowledged by the principles and methods applied to the admissible facts or data.

Thus, the expert uses techniques, science knowledge, methodology and professional practices to provide quality services. To obtain such quality, the accountant should always be specializing, because the hiring of his services depends both in the cost as well as in the quality of the offered services. The quality of services can be understood not only as the good technique, but it should also consider the need of satisfying the client, which happens when the client notices that the result of his request meets the expectations (ROCHA; SANTOS, 2004).

According to the understanding of Sá (2010, p. 9), "the quality of the professional almost always governs the quality of the executed work. However, there are essential requirements to regard an expert investigation as a quality one".

Therefore, a good expert work shall unfailing have the following:

"Objectivity - characterized by the expert action of not deviating from the matter motivating the issue.

Accuracy - consists of offering pertinent and appropriate answers to the questions formulated or the proposed purposes.

Clearness - is in using in his opinion an accessible language to the user of his work, although it might preserve the technological and scientific terminology in his reports.

Fidelity - is characterized by not being influenced by third parties, nor by 
reports that do not have competent materiality and consistency.

Concision - consists of avoiding to be prolix, and to issue an opinion that can clearly facilitate decisions.

Reliability - consists of having an expert work supported in unmistakably, and legally and technologically valid elements. At last, the full attainment of the purpose is exactly the result of the work being coherent with the reasons giving rise to it.” (SÁ, 2010, p. 10)

Sá (2010), however, points out that there are guidelines to be followed to make a good use of the accounting expert work technology, namely:

1. Good identification of the objective.

2. Competent planning of the work.

3. Execution of the work based on unmistakable evidences, fully and totally reliable.

4. Being very cautions in making conclusions, and only issued then after being absolutely sure about the results.

5. Finalize it in a clear, precise, and unmistakable way.

Summarizing the quality aspects, and complementing the procedures necessary for planning and executing the accounting expert work, Ornelas (2003) says that the accounting expert report should show the contents in a logically and technically correct way, which obliges the accounting expert to think creatively of how to offer an intelligible technical piece for his readers, with impeccable technical qualities, which allows to understand the outlines of the lawsuit, the controversial facts demanding the technical evidence, as well as the positive or negative certification of such very facts.

For that end, Sá (2010, p. 13) assures that "the expert should not save explanations that justify his work and that offer the maximum possible reliability for its users". However, according to Ornelas (2003, p. 91), if the accountant-expert "intends to be understood by his readers, it should use words that, without losing the accounting meaning, are intelligible for them, in the case, the judge and the counselors to the parties".
As a conclusion, the contributions of Sá (2010) and Ornelas (2003) allow to infer aspects indispensable to the quality of the accounting expert reports, in which requirements that can benefit the legitimacy of the expert report were introduced, as well as the understanding and acknowledgement of the expert work to solve disputes,

\subsection{Similar studies on the relevance and quality of the accounting expert work}

With the aim of identifying similar studies on the topic of this work, we have conducted a research in periodicals of the accounting area. As the results of such survey, we decided to present four works published in the period 2006 to 2012. The approach of such studies is presented as follows.

The study of Leitão Júnior et al. (2012), which had the aim of knowing the opinion of a tenured judge in a civil court in the city of São Paulo about the relevance of the accounting expert work, in the lawsuit, allowed us to realize that the report is an important and necessary piece for the Judge's decision-making process. It was evidenced that the accounting expert report helps the judge to clear up the dispute among the parties.

In the study of Cestare, Peleias and Ornelas (2007), which had the purpose of evaluating how the accountant-experts of a legal sphere elaborated their reports, and to check whether there are expressive differences between the practice and the proposition of the doctrine and of the Federal Council of Accountancy, the result was that, despite expressive divergences were not found, important omissions were observed, such as the almost total absence of the recording of the diligences documents, and the total suppression, in the examined reports, of the indication, under the signature, of the professional category of the accounting expert.

To Neves Júnior and Rivas (2007), who have developed an study with the aim of verifying the quality of the accounting expert report and its influence on the judge's decision, given the importance of such technical evidence for the 
formation of the legal conviction of the judge, the result was that most of the accounting expert reports meets the requirements of the works conducted with quality, and it was proved that this expert evidence influences the judge's decision.

In another study developed by Neves Júnior and Medeiros (2006), in which the main objective was to check the quality of the works performed by the accountant-experts in the view of those most using their services (the judges), it was possible to evidence that the reports produced by the experts are good, although some problems were highlighted, such as the lack of the description of parameters and their grounds for the elaboration of reports; the use of excessively refined texts; the excessive utilization of technical words; and the use of ambiguous or imprecise words.

As the summary of such researches, it is possible to evidence the importance of the accounting expert report for the judge's decision; there are though things to say about the quality of such expert report. The methodological approach of the application of such researches with the use of the analysis of documents and field survey should also be highlighted.

About this study, the difference is the conduction of a survey within the sphere of the Labor Court System, aiming to analyze the relevance and the quality of labor expert works by getting the opinion of judges working in the Brazilian Labor Court System.

\section{FIELD SURVEY}

\section{I Summary of the survey}

The article has the purpose of introducing the results of a field survey conducted in the months of February and March/2011, in which questions were made to trial judges working in the Labor Court System, aiming to obtain their opinions on the quality and relevance of the work performed by the accountant-expert in disputes in the labor field, in addition to evidencing information about the main failures committed by such accountant-experts, and presenting proposals for improvement.
According to Vergara (2000), this survey could be classified as descriptive, methodological and field survey. The field survey was conducted by applying a questionnaire to the population of 1,094 trial judges working in the Labor Court System in all the Brazilian regions, and who took part of the courses of the National School of Labor Judges Formation and Enhancement (Enamat) in 2010.

\subsection{Surveyed universe}

In Brazil, there are 2,716 trial judges working in the Labor Court System. Considering the total number of positions in the Labor Court System, there are 1.88 judges for each group of 100,000 inhabitants.

The target group of the survey was the 1,094 judges taking part of the Enamat training in 2010. These respondents were selected for being users of the expert reports submitted by the accountant-expert, and because of the easy access to the e-mail contacts.

About the definition of the sample, a confidence interval of $90 \%$ was used, with an error margin of 5\%, which resulted in a sample of 218 judges for the application of the questionnaire.

Considering that only 135 questionnaires were returned, the sample was classified as nonprobabilistic and intentional.

\subsection{Questionnaire}

The questionnaire was structured in two parts. Part "A" presented the characteristics of the judges, where the relevant descriptive aspects of the respondents were addressed. Part " $\mathrm{B}$ " is composed of affirmations containing 18 questions, 17 being closed affirmative ones, and 1 being open, allowing to identify the perception of the judges in relation to the accountant-expert work in the labor field (Appendix A).

As a standard of answer, the Likert scale was used for the affirmative questions: (1) Totally disagree, (2) Disagree, (3) Indifferent, (4) Agree, and (5) Totally agree. For the discussion of results, the scale Agree and Totally agree was considered 
as acceptance of the affirmation, and Disagree and Totally disagree as non-acceptance of the proposed affirmation.
About the theoretical fundaments used for the elaboration of the questionnaire, the doctrine presented as follows by the authors was used:

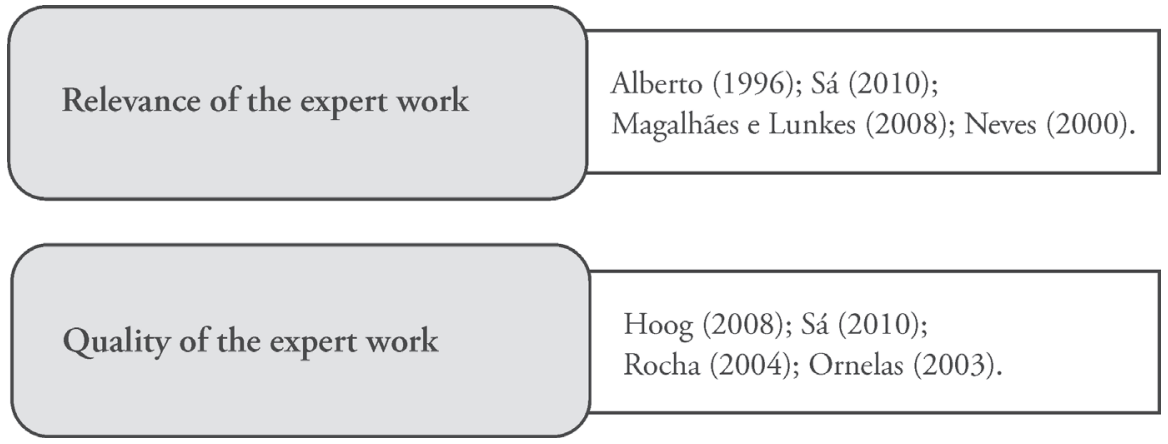

FIGURE 1 - Fundaments used to formulate the questionnaire

Source: the authors.

\subsection{Protocol of the survey}

The procedures outlined for the survey, following the survey protocol model suggested by Yin (1989), were structured in three stages: Definition, Data Collection, and Results Analysis.

The procedures conducted in the definition stage address the determination of the methodology to be applied in the survey and in the construction of the literature review. In the data collection stage, the survey questionnaire was elaborated, the pretesting was done, adjustments were done to the final questionnaire, which was then applied. In the analysis of data, the data processing procedures, analysis, results, conclusions, and recommendations are presented.

\section{$4 \quad$ RESULTS}

The results described in this section were analyzed from the answers to the questionnaire applied to the Labor Court judges participating in the survey, and have the aim of allowing the study of the research topic outlined for the work. For the data analysis the software SPSS (Statistical Package for the Social Sciences) was utilized.

\section{I Characteristics of the respondents}

The judges who were respondents of the questionnaires have the following characteristics: $57 \%$ are men, $43 \%$ are women. The average age was 42 years. The professional experience was in average of 12 years in the position. As for their qualification, 50.4\% informed to have attended a specialization course. As for the geographic region, $45.5 \%$ of the respondents are from the south region, and $23.5 \%$ of the Southeast region, and the state of São Paulo had the biggest number of respondents - 33.3\% -; with 10.6\%, Campinas (SP) was the city with the higher number of respondents.

The analyzes of the survey results are presented as follows. The analysis was conducted in two moments: the first one, where all the cases were studied without identifying similarities amongst them (characteristics and answers to the questionnaires); the second one, in which the application of the statistical cluster analysis technique was done, with the aim of identifying the similarities amongst answers and the characteristics of respondents, and the possible discrimination of such results. 


\subsection{Analysis of answers without defining clusters}

It was asked whether the answers given by the expert are appropriate for the questions asked in the lawsuit. $88.9 \%$ agree or totally agree with this statement. With such percentage, we observe that the expert appropriately answer to the dispute questions, and according to Sá (2010, p. 10), "the full satisfaction of the purpose is exactly the result of the work being coherent with the reasons giving rise to it". It was said that the experts could improve the quality of their reports, mainly the answers to the requirements, submitting other arguments in addition to those already submitted, in order to convince the judge and the parties about his statements.

Then, it was asked about the position of the expert in not deviating from the matter that gave rise to the issue. $84.4 \%$ agreed or totally agreed with the statement. We can infer that the experts keep the objectivity, and do not deviate from the issue formulated. However, it was said that it is not uncommon seeing the expert getting into legal discussions, deceitfully launched by the legal counselors, getting away from the technicalaccounting contents that should be the object of their work.

It was said that the expert cares about the fidelity of their answers, not being influenced by third parties, nor by reports that do not have competent materiality and consistency. The result showed $81.5 \%$ of agreement to that statement. Therefore, the conclusion was that the expert keeps and takes care of the fidelity. However, it was said that many times, biased expert reports are submitted, based on testimonies given by the parties that were following the conduction of diligences.

When asked whether the expert is concise when writing his report in order to avoid being prolix and to issue an opinion that can facilitate decisions, the result was $75.2 \%$ of respondents who agree or totally agree with that, while $18.8 \%$ disagree or totally disagree, and $6 \%$ were indifferent. According to Ornelas (2003, p. 91), "if the accountant-expert intends to be understood by his readers, it should use words that, without losing the accounting meaning, are intelligible for them, in the case, the judge and the counselors to the parties". Thus, it was said that the expert should bear in mind that the judge is not a specialist in expert matters, which is why the former should write his report with a good and clear language, avoiding the excess of technical words.

It was said that the accountant-expert presents in his report answers that are pertinent and duly grounded about the dispute, without only limiting to the demonstrations of calculations. The result showed that $51.8 \%$ agree or totally agree with such statement, while $32.6 \%$ disagree or totally disagree, and $14.1 \%$ were indifferent to the treatment given by the expert to the argumentation shown in the answers to the questions comprised in the expert report. It was argued that, in some cases or in the particulars of some cases, the expert needs to argue more to convince the parties about his conclusions, as well as in regard to the Court itself, since in complex matters it is necessary to invite the expert to personally explain his conclusions.

It was asked if the calculations are presented in a clear and easily understandable way; as the result, $68.9 \%$ of the respondents agree or totally agree with the statement, while $19.6 \%$ disagree or totally disagree, and $11.5 \%$ were indifferent. Such results corroborate the need of following the recommendations done by Neves (2000), saying that the procedures adopted for the calculations should be explained, to ensure the legitimacy and the transparency of the work conducted by the expert. Furthermore, such procedure can contribute for the speedup of the lawsuit. Therefore, we can infer that well made calculations favor the procedures regarding the lawsuit.

In regard to the technical language used by the experts, $73.7 \%$ disagree or totally disagree that the expert reports excessively use the technical language, while $14.3 \%$ agree and $12 \%$ are indifferent to this statement. This result confirms the understanding of Ornelas (2003) that ambiguous or imprecise words should not be used at all, and the text should be 
constructed with words only admitting a single meaning. Furthermore, the judges informed that, sometimes, reports are submitted using a language making it difficult to understand, not allowing to the parties the full comprehension of the expert work. Therefore, the technical language should be enhanced, putting the subjectivity aside in the answers to the questions asked.

In regard to the achievement of the expert work objectives, it was asked whether the expert report in the labor field is well grounded, and whether it meets the requirements of objectivity and accuracy when formulated. It was observed that $69.9 \%$ agree or totally agree with this statement, while $17.3 \%$ disagree and $12.8 \%$ are indifferent. This result confirms the need of using essential requirements for the expert work to be regarded as a quality work (SÁ, 2010). It was also possible to observe that most of the experts submit reports that contribute to the solution of disputes. Thus, the experts make extremely complex calculations, allowing a clear and objective view of the amounts under analysis.

These results analyze the quality of the expert report, and it was possible to observe that the judges recognize the expert work as being of good quality; however, it is possible to infer the need of improving the expert work, in regard to the objectivity, the language used, and for the easy comprehension of the expert report.

Such observations corroborate similar studies conducted by Neves Júnior and Medeiros (2006) and Neves Júnior and Rivas (2007), in which, respectively, through a field survey conducted with the judges and an analysis of documents produced by the experts, it was observed the need to improve the expert work, regarding the description of parameters and their grounding for the elaboration of reports, the use of extremely refined texts, the excessive use of technical terms, and the use of ambiguous or imprecise words.

The survey has also investigated the degree of trust of the judges in regard to the work developed by the accountant-experts, stating that the information presented in the answers given by such experts are reliable. As the result, $76.7 \%$ of the respondents regard the expert work as reliable and totally reliable, while $23.3 \%$ regard it as more or less, or little reliable. Here stays the reflection that can be inferred from the recommendations presented by Sá (2010, p. 11), that "the quality of the expert work is reflected on how reliable his report and opinion is in the eyes of those using them". It is noteworthy that the technical quality of the expert work, and the maintenance of the mutual trust - judge and expert - are directly related to the intensity of the judge activity, within the sphere of the expert evidence.

It was also possible to evidence that in the opinion of the judges, the experts can contribute with the justice by offering subsidies for the elaboration of judgments, informing the judge which the most recurring issues are, in order to better clear up the topic for future trials.

In another statement, we tried to evidence if the expert report allows identifying whether the expert has full knowledge of the facts which are being disputed. The results revealed that $75 \%$ agree or totally agree with that, while $20.9 \%$ disagree or totally disagree, and $11.4 \%$ are indifferent. Corroborating this result, we highlight the statement of Ornelas (2003) that points out to the need of planning specific actions and procedures for each case, and that the expert work requires from the expert a high power of knowledge and technical creativity. About this issue, the judges added that a good expert work also is related to the full access of such professional to the understanding of the judge, which can allow the formalization of the expert work considering such criteria.

As for the statement that the accounting expert offers the report in order to allow an easy reading, we observed that $65.9 \%$ of the respondents agree or totally agree with the easiness to read of an expert report, while $20.4 \%$ disagree or totally disagree, and $13.6 \%$ are indifferent to that. It was mentioned that, in the conclusion of a report, many experts only answer the questions made, without describing them, which makes the report analysis difficult, being very import to submit it in a clear and conclusive way, regarding the objective of the expert work. 
It was also asked to the judges to evaluate the work developed by the accountant-expert. $58 \%$ of the surveyed judges consider them as good and indispensable; $36.6 \%$ said they meet the needs, and $5.4 \%$ said they are of little quality. It was also verified that some few experts develop works with excellence and have irreproachable work, but because of the amount of work they have, they not always accept all the works, forcing the appointment of other professionals, not always so committed as the formers. It should be highlighted that good experts have the advantage of remaining in the expert work market. It is also important to highlight that the experts have the main objective of meeting the expectations of their main customer: the judge.

In regard to the technical competence, there was the following statement: the expert convinces the parties involved in the lawsuit, through its technical competence, that the lawsuit issue was totally cleared up. The results revealed a distributed perception among the answers given, since $39.4 \%$ agree or totally agree, $34.1 \%$ disagree or totally disagree, and $26.5 \%$ are indifferent. It was said that some experts elaborate irreproachable expert reports, with the indication of all necessary elements both for the formation as well as the liquidation of the lawsuit, while others put themselves in the position of a judge, intending to decide the lawsuit instead of providing the objective necessary information for the judge to do that.

Subsequently, it was asked whether the expert report in the labor field is the conclusive tool to determine the judgment. It was observed that $56.1 \%$ agree or totally agree with this statement, while $33.4 \%$ disagree or totally disagree, and $12.8 \%$ are indifferent. . It was stated that the expert work is very important to elucidate technical issues, although the judge does not use them exclusively to form his convincement about the conclusions in the report.

As for the relevance of the report, it was asked whether the expert report is determinant for the liquidation of the judgment. $71 \%$ of the respondents regard the expert report as relevant and very relevant, $14.5 \%$ said that it contributes to the judgment, and $14.5 \%$ regard it as irrelevant or indifferent. It was pointed out that the accountant-expert role is essential in the delivery of the jurisdictional service, because it will make the judgment concrete, transforming the requests approved by the court into amounts.

Based on the statement that the legal accounting expert is originated in the need of the judge to elucidate the facts of a lawsuit, to clear up and to issue a decision, it was asked about its relevance for the judge's decision. $87,8 \%$ of the respondents agree or totally agree that the report is relevant for the judge's decision. It was said that, depending on the matter discussed in the records, the accounting expert work is an indispensable tool for the judge to form his belief.

The results shown in this survey confirm the understanding of similar studies conducted by Leitão Júnior et al. (2012), Neves Júnior and Medeiros (2006), Cestare, Peleias and Ornelas (2007), Neves Júnior and Rivas (2007) about the relevance of the accounting expert report as an important and necessary instrument for the judge's decision-making process.

In addition, the opinion of the judges was also obtained regarding items that could be improved in the work of the accountant-expert, such as the technical language, objectivity and accuracy of answers, argumentation, exactitude and clearness. There were 90 indications for the improvement of the objectivity and accuracy of the answers, 75 indications for the improvement of the report clearness, and 49 indications for the improvement of argumentation, having said that a weak argumentation, with no ground, makes the evidence fragile, which causes, in the execution phase, many embargos and contestations of the calculations, delaying the lawsuit.

Also aiming to obtain inputs for the discussion of the article, a complementary question was made asking the respondents to tell some considerations about the quality of the accountant-expert work. The summary of such answers in the form of improvement points and highlights is presented as follows. 


\subsection{Improvement points and highlights}

In regard to the quality aspect, the following considerations were made:

- The accountant-expert, even because of its qualification, tends to be very objective in his work, which is extremely favorable. However, as for the clearness and the argumentation, it cannot be considered as easy understandable by people who do not have a certain technical knowledge, such as a complainer disputing without a legal counselor.

- There is the suggestion of enhancement courses. There are cases where the experts transcribe the report arguments from the Internet, without mentioning the source, making the evidence fragile and delaying the lawsuit. In other cases, the experts are inconclusive. These are minority, but even though they cause concern.

- Most of the accountant-experts in the labor field respects the deadlines defined by the Court, and shows a constant quality in their reports. Those submitting a poor quality work are excluded from the staff of experts, and hardly find a position in another Labor Court.

- The experts are important to help the Judges in their judgments, but some of them need updating.

About the relevance of the accounting expert work for the judge, the following comments were presented:

- It is very important, because the accounting expert work is many times the biggest support the judge has to liquidate the judgment.

- It is essential to form the convincing of the judge.

- It is very important to judge the lawsuit.

- In the labor field, it is relevant and presents a good quality report.
- It is very helpful in the elaboration of complex calculations, and also to avoid the interruption of the proceeding due to the great number in the liquidation phase.

Another important points:

- There is no doubt that, in the pursuit for the correct decision, the accountingexpert work is fundamental in the Labor Court System. Considering the expenses incurred with this type of expert work, however, the State should create expert positions through the law, and promote entrance exams to hire public experts, which will surely result in smaller expenses in the cases where the free legal assistance is provided.

- There should be joint work between the staff of experts and the administration, keeping a centralized registry, and in case of approval of free legal assistance, the experts should be fairly remunerated by the Federal Authorities.

- In regard to the arbitrage of fees, amounts compatible with the work presented should be proposed, especially because it is important to keep the good professionals.

About the indications of improvement for the accountant-experts work, it is noteworthy that they are compatible with the need of a better qualification for such professionals, which could contribute to the improvement of the accounting expert report, which is intrinsic in the observations of this study and similar studies done by Leitão Júnior et a. (2012), Neves Júnior and Medeiros (2006), Cestare, Peleias and Ornelas (2007), Neves Júnior and Rivas (2007).

\subsection{Analysis of answers from the definition of clusters}

After the analysis of the results considering all the survey cases, the statistic technique of cluster analysis was applied - for the identification of possible similarities and distinctions amongst 
the cases (characteristics and answers by the respondents).

To that end, the SPSS application was used, through the execution of the analyzel classify/two step cluster procedure. Firstly, the automatic definition of the cluster number was done, and the result was a single cluster that was disregarded for the analysis, since the analysis of all cases in a single cluster had already been done. Then, a new cluster analysis was done, determining the number of clusters as two and three. As the result, we have decide to analyze the cases in three clusters, since the composition of two clusters have evidenced a very different distribution in regard to the amount of cases in such clusters. Table 1 shows the characteristics of the analyzed clusters:

TABLE 1 - Composition of clusters

\begin{tabular}{l|c|c|c|c|c|c}
\hline Cluster & Respondents & Percentage & Average Age & $\begin{array}{c}\text { Average Experience } \\
\text { Years }\end{array}$ & Women & Men \\
\hline Cluster 1 & 39 & $31.5 \%$ & 40 & 11 & $20 \%$ & $40 \%$ \\
\hline Cluster 2 & 51 & $41.1 \%$ & 44 & 13 & $50 \%$ & $33 \%$ \\
\hline Cluster 3 & 34 & $27.4 \%$ & 40 & 10 & $30 \%$ & $27 \%$ \\
\hline Total & 124 & $100 \%$ & 42 & 12 & $100 \%$ & $100 \%$ \\
\hline
\end{tabular}

Source: the authors.

\subsection{Characteristics of the clusters}

About the characteristics of the clusters, it was possible to evidence them from the analyses conducted of the cases classified in their respective clusters. The method of analysis was the highlight of predominant characteristics of the clusters, by using the descriptive statistic technique. However, it is noteworthy that of the 135 questionnaires answered, 11 cases were disregarded for analysis because it was not possible to obtain all the information from the survey questionnaire, either because of the interviewee characteristics or because of the issues presented. Therefore, 124 were considered for cluster analysis, classified as follows: 39 are classified in cluster 1, 51 in cluster 3 , and 34 in cluster 3 .

From the characteristics presented, cluster 1 was identified as composed mostly by men, with average age of 40 years, and 11 years of experience in the position of judge; most has specialization and present, in a balanced way, the South and Northeast regions of Brazil. Cluster 2 was constituted by the group with more cases classified and with more women; it is the most experienced group, with average age of 44 years, and 13 years of experience in the position, having specialization, and mostly represents the South region. Cluster 3 is the smallest group, with average age of 40 years, and smaller experience, only 10 years of profession, and mostly represents the Southeast region. Therefore, the main distinctions of case classification as for the respondents' characteristics were gender, age and experience time of the judges.

In regard to the questions asked, we highlight that in cluster 1 , its members disagree or totally disagree with the following aspects: objectivity, fidelity and concision of the report, as for the fact of the answers being pertinent and based on the lawsuit, as for the expert report and the calculations being presented in a clear and easily understandable manner, as for the statement that the report meets the requirements with objectivity and accuracy. They disagree that the experts have full knowledge of the facts, and that they offer reports in order to allow an easy reading. They evaluate the expert work as of little quality, and they consider that it meets the needs. They disagree that the expert work convinces through the technical competence, and that the report is a conclusive tool to determine the judgment. They agree that the experts use an excessively technical language.

In general, we notice that cluster 2 and 3 agree or totally agree with the development of the experts' answers to the expert work, with objectivity, fidelity and concision of the report in order to avoid being prolix. They agree that the 
answers are pertinent and based on the lawsuit, and that the expert report and calculations are presented in a clear and easily understandable way. They regard the answers as more or less reliable. They agree that the expert report shows that the experts have full knowledge of the facts, and that they offer reports in order to allow an easy reading. They evaluate the expert work as good, and they consider that it meets the needs. The agree that the expert work convinces through the technical competence, that the issue was totally cleared up, and that their report is a conclusive tool to determine the judgment, it is well grounded and meets the requirements of objectivity and accuracy. They disagree that the experts use an excessively technical language.

Thus, it is possible to infer that in cluster 1 there is a concentration of judges skeptical in relation to the expert work, while in clusters 2 and 3 they agree more with the quality and relevance of the work conducted by such professional. For clusters 2 and 3, however, the main distinction was the characterization of respondents.

\section{FINAL CONSIDERATIONS}

As for the objective proposed in this article, we can say that it was attained once the aspects related to the quality and relevance of the accountant expert work in the labor field disputes were evidenced.

Amongst the main results, it was ratified, in the opinion of the interviewees, that the expert work is essential for the formation of the convincement of the judge, and that the expert properly answers to the lawsuit questions, using the accounting expert report as an indispensable tool for the judge belief, since $76.7 \%$ of the interviewees showed to trust in the information provided in the answers to the questions, and for $69.9 \%$ of the respondents, the expert report in the labor field is well ground, and meets the requirements of objectivity and accuracy, and the calculations are presented in a clear and easily understandable way, in the opinion of $68.9 \%$ of the respondents.
This study allows to ratify a previous survey, which addressed the topic of quality of the works produced by accountant-experts, which results pointed out that such works could be considered as of good quality (average rating: 7.43 points) for approximately $70 \%$ of the interviewed judges. The results of the study that showed the influence of the report in the judge's decision are also confirmed, in which it was observed that reports can attain the objective of elucidating and clearing up the doubts of the judge.

Furthermore, it was also possible to evidence the points of improvement for the development of the accountant-expert work, including:

- There is the need of a better qualification of experts working in the Labor Court System. The expert report is a key-piece and contributes to the elaboration of the judgment.

- Some expert works done in the liquidation are not yet capable of faithfully following the provision of a judgment, which leads the judge to order the report rectification.

- Some items depending on the judge's understanding should be cleared up before the elaboration of the report, to avoid supplementations and explanations, because this delays the progress of the lawsuit.

- Experts should better ground the conclusions in their works.

It is noteworthy that there are limitations in this survey in regard to the size of the sample. This work is though relevant because there are few researches on the studied topic, and the results obtained in this study allow, especially for the accountant-expert, the opportunity to reflect, know and analyze the opinion of judges about their work, and they can use such tool to expand their knowledge, identify possible failures, and invest in a constant updating. Furthermore, the hypothesis raised in this research can be proved in further works, in which it will be possible to develop new surveys aiming to propose initiatives for the improvement of the accountant-expert qualification, and a technical competence 
certification process to insert and value this professional in the job market.

\section{REFERENCES}

ALBERTO, V. L. P. Perícia contábil. São Paulo: Atlas, 1996.

ANGER, A. J. (Coord.). Consolidaçáo das leis do trabalho. 10. ed. São Paulo: Rideel, 2004.

BRASIL. Código de processo civil. 18. ed. São Paulo: Saraiva, 2003.

CAVENAGE, A. E. Reflexóes sobre a presença do contador nas açóes trabalhistas. 2004. Disponível em: <http://www.contadorperito. com/index.php?tp=3\&ag=7792>. Acesso em: 08 set. 2010.

CARVAlho, E. B.; MARQUES, C. Perícia contábil nas relaçóes de trabalho em processos judiciais. Enfoque: Reflexão Contábil, Maringá, v. 24, n. 2, p. 19-35, 2005. Disponível em: <http:// periodicos.uem.br/ojs/index.php/Enfoque/ article/view/5787/3631>. Acesso em: 21 out. 2010 .

CESTARE, T. B.; PELEIAS, I. R.; ORNELAS, M. M. G. O laudo pericial contábil e sua adequação às normas do Conselho Federal de Contabilidade e à doutrina: um estudo exploratório. Revista de Contabilidade do Mestrado em Ciências Contábeis da UERJ, Rio de Janeiro, v. 12, n. 1, p. 1, jan./abril, 2007. Disponível em: <http://www. atena.org.br/revista/ojs-2.2.3-09/index.php/uerj/ article/viewFile/79/79>. Acesso em: 31 out. 2012.

C O N S L H O FE D E R A L D E CONTABILIDADE. Resoluçáo CFC n 1.244, 10 de dezembro 2009a. Aprova a NBC PP 01: Perito Contábil. Disponível em: <http://www. cfc.org.br/uparq/NBC_PP_01.pdf>. Acesso em: 05 ago. 2010.

Resolução CFC n 1.243, 10 de dezembro de 2009b. Aprova a NBC TP 01:
Perícia Contábil. Disponível em: <http://www. cfc.org.br/uparq/NBC_TP_01.pdf>. Acesso em: 05 ago. 2010.

GRAY, D. Forensic accounting and auditing: compared and contrasted. American Journal of Business Education, Colorado, v. 1, n. 2, p. 115-126, Fourth Quarter, 2008. Disponível em: <http://journals.cluteonline.com/index.php/ AJBE/article/download/4630/4719>. Acesso em: 22 set. 2010.

HONORÁRIOS periciais na justiça do trabalho: resolução 35 do CSJT. 2007. Disponível em: <http://amatraxviii.blogspot.com/2007/11/ honorrios-periciais-na-justia-do.html $>$. Acesso em 05 out. 2010.

HOOG, W. A. Z. Prova pericial contábil: aspectos práticos e fundamentais. 5. ed. Curitiba: Juruá , 2008.

LEITÃO JÚNIOR, L. R. D. et al. Relevância do laudo pericial contábil na tomada de decisão judicial: percepção de um juiz. RIC: Revista de Informação Contábil, Pernambuco, v. 6, n. 2, p. 21-39, abr./jun. 2012. Disponível em: <http:// www.revista.ufpe.br/ricontabeis/index.php/ contabeis/article/view/291/291>. Acesso em: 31 out. 2012.

MAgalhâes, A. D. F., et al. Perícia contábil. São Paulo: Atlas, 1998.

; LUNKES, I. C. Perícia contábil nos processos cível e trabalhista. São Paulo: Atlas, 2008.

NEVES, A. G. Manual de cálculos para liquidação de sentença trabalhista. 2. ed. São Paulo: LTR, 2000.

NEVES JUNIOR, I. J.; RIVAS, I. I. V. A qualidade do laudo pericial contábil e sua influência na decisão de magistrados nas comarcas localizadas no Distrito Federal e na cidade de Fortaleza/ CE. RBC: Revista Brasileira de Contabilidade, Brasília, v. 36, n. 168, p.75-90, nov./dez. 2007. 
; MEDEIROS, T. A. A qualidade do laudo pericial elaborado pelo perito contador na visão de magistrados do Rio de Janeiro e Brasília. RBC: Revista Brasileira de Contabilidade, Brasília, v. 35, n. 159, p.45-57, maio/jun. 2006.

ORNELAS, M. M. G. Perícia contábil. São Paulo: Atlas, 2003.

ROCHA, L. A.; SANTOS, N. Manual de perícia contábil judicial. Goiânia: Max , 2004.

SÁ, A. L. Perícia contábil. 9. ed. São Paulo: Atlas, 2010.
TRIBUNAL SUPERIOR DO TRABALHO TST. Relatório geral da Justiça do Trabalho. 2009. Disponível em: <http://www.tst.jus.br/ documents/10157/ce9d46fe-9f6a-4fcf-94d4f81c55a38dff>. Acesso em: 08 ago. 2010.

VERGara, S. C. Projetos e relatórios de pesquisa em administração. São Paulo: Atlas, 2000.

YIN, R. K. Case study research: design and methods. Newbury Park, CA: Sage Publications, 1989. 


\section{APPENDIX A - SURVEY QUESTIONNAIRE}

\section{Part 1: Characterization of the Survey:}

1. Gender:

Woman Man

2. Age:

3. Time of experience: years

4. Education background

( ) Graduation ( ) Specialization ( ) Master's ( ) PhD

5. Geographic region

( ) North ( ) Northeast ( ) Mid-West ( ) South ( ) Southeast

6. Federation Unit where he/she is working:

7. Work site:

\section{Part 2: Questions:}

1. The answers presented by the expert are appropriate for the questions asked.

\begin{tabular}{|l|l|l|l|l|}
\hline Totally agree & Agree & Indifferent & Disagree & Totally disagree \\
\hline 5() & 4() & 3() & 2() & 1() \\
\hline
\end{tabular}

2. The expert shows objectivity by not deviating from the matter motivating the issue.

\begin{tabular}{|l|l|l|l|l|}
\hline Totally agree & Agree & Indifferent & Disagree & Totally disagree \\
\hline 5() & 4() & 3() & 2() & 1() \\
\hline
\end{tabular}

3. The expert cares about the fidelity of his answers, not being influenced by third parties, nor by reports that do not have competent materiality and consistency.

\begin{tabular}{|l|l|l|l|l|}
\hline Totally agree & Agree & Indifferent & Disagree & Totally disagree \\
\hline 5() & 4() & 3() & 2() & 1() \\
\hline
\end{tabular}

4. The expert shows the use of concision in his report, in order to avoid prolixity, and to issue an opinion that can facilitate the decisions.

\begin{tabular}{|l|l|l|l|l|}
\hline Totally agree & Agree & Indifferent & Disagree & Totally disagree \\
\hline 5() & 4() & 3() & 2() & 1() \\
\hline
\end{tabular}


5. The expert in the labor field presents in his report answers that are pertinent and duly grounded about the dispute, without only limiting to the demonstrations of calculations.

\begin{tabular}{|l|l|l|l|l|}
\hline Totally agree & Agree & Indifferent & Disagree & Totally disagree \\
\hline 5() & 4() & 3() & 2() & 1() \\
\hline
\end{tabular}

6. The expert report and the calculations are presented in a clear and easy understandable manner.

\begin{tabular}{|l|l|l|l|l|}
\hline Totally agree & Agree & Indifferent & Disagree & Totally disagree \\
\hline 5() & 4() & 3() & 2() & 1() \\
\hline
\end{tabular}

7. The experts use an excessively technical language.

\begin{tabular}{|l|l|l|l|l|}
\hline Totally agree & Agree & Indifferent & Disagree & Totally disagree \\
\hline 5() & 4() & 3() & 2() & 1() \\
\hline
\end{tabular}

8. The expert report in the labor field is well grounded and objectively and precisely answers the formulated questions.

\begin{tabular}{|l|l|l|l|l|}
\hline Totally agree & Agree & Indifferent & Disagree & Totally disagree \\
\hline 5() & 4() & 3() & 2() & 1() \\
\hline
\end{tabular}

9. The information presented in the answers to the questions submits reliable results.

\begin{tabular}{|l|l|l|l|l|}
\hline Totally reliable & Reliable & More or less reliable & Little reliable & Very little reliable \\
\hline 5() & 4() & 3() & 2() & 1() \\
\hline
\end{tabular}

10. The expert report evidences that the expert has full knowledge of the facts which are being disputed.

\begin{tabular}{|l|l|l|l|l|}
\hline Totally agree & Agree & Indifferent & Disagree & Totally disagree \\
\hline 5() & 4() & 3() & 2() & 1() \\
\hline
\end{tabular}

11. The accountant-expert offers an easy-to-read report.

\begin{tabular}{|l|l|l|l|l|}
\hline Totally agree & Agree & Indifferent & Disagree & Totally disagree \\
\hline 5() & 4() & 3() & 2() & 1() \\
\hline
\end{tabular}

12. The works developed by the accountant-expert can be evaluated, in general, as:

\begin{tabular}{|l|l|l|l|}
\hline Good & Indispensable & Meet the needs & Of little quality \\
\hline 4() & 3() & 2() & 1() \\
\hline
\end{tabular}


13. The work presented by the expert convinces the parties involved in the lawsuit, through its technical competence, that the lawsuit issue was totally cleared up.

\begin{tabular}{|l|l|l|l|l|}
\hline Totally agree & Agree & Indifferent & Disagree & Totally disagree \\
\hline 5() & 4() & 3() & 2() & 1() \\
\hline
\end{tabular}

14. The expert report in the labor field is the conclusive tool to determine the judgment.

\begin{tabular}{|l|l|l|l|l|}
\hline Totally agree & Agree & Indifferent & Disagree & Totally disagree \\
\hline 5() & 4() & 3() & 2() & 1() \\
\hline
\end{tabular}

15. The expert work report is determining for the judgment liquidation.

\begin{tabular}{|l|l|l|l|l|}
\hline Relevant & Very relevant & Indifferent & Irrelevant & Contributes to the judgment \\
\hline 5() & 4() & 3() & 2() & 1() \\
\hline
\end{tabular}

16. The expert work report is relevant for the judge's decision.

\begin{tabular}{|l|l|l|l|l|}
\hline Totally agree & Agree & Indifferent & Disagree & Totally disagree \\
\hline 5() & 4() & 3() & 2() & 1() \\
\hline
\end{tabular}

17. Which aspects can be enhanced in the work of experts:

( ) Technical language

( ) Objectivity and accuracy in the answers

( ) Argumentation

( ) Accuracy

( ) Clearness

18. Would you like to expose your viewpoint on the relevance and quality of the expert work in the labor field? 